\title{
Oral administration of baker's yeast (Saccharomyces cerevisiae) acts as a growth promoter and immunomodulator in Labeo rohita (Ham.)
}

\section{ArupTewary and Bidhan C Patra*}

Aquaculture Research Unit, Department of Zoology, Vidyasagar University, Midnapore- 721 102, West Bengal, India

\begin{abstract}
The effect of baker's yeast (Saccharomyces cerevisiae), in the diet of the Rohu (Labeo rohita) innate immune response were investigated. Indian major carps Labeo rohita were fed with four different diets for eight weeks: a formulated diet as control diet and the same diets supplemented with $5 \%, 7.5 \%$ and $10 \%$ baker's yeast as an experimental diets. After every fifteen days interval different growth parameters ( such as ADG, SGR, FCR and PER), Serological parameters ( such as TSP,TSA, TSG and A:G), different Hematological parameters ( such as TLC, TEC, Hct, MCV and MCH ) and different Non- specific immunological parameters ( such as PR, PI, Respiratory Burst activity) were evaluated during experimental trial. At the end of the experimental period, fishes of all the tanks were challenged with pathogenic bacteria Aeromonas hydrophila. The results show that, yeast cell wall able to enhance the innate immunity and also have a positive co-relation with growth parameters. Through the absorption of yeast wall particle, the immune function and disease resistance of the entire organism is stimulated. These results support the possible use of baker's yeast as natural immunostimulants in common fish diets.
\end{abstract}

Keywords: Immunostimulant; Labeo rohita; Saccharomyces cerevisiae

\section{Introduction}

Several whole microorganisms, live or not, such as bacteria, fungi or algae, increase disease resistance in mammals and fish $[1,2]$. In fish, as in other aquatic organisms, the whole microorganisms administered have mainly been bacterial species, which in the form of feed additives, have been shown to improve the intestinal microbial balance and increase the health status of fish, seemingly by colonising the gut and acting as antagonists to pathogens and so increasing resistance to pathogens $[1,3,4]$.More recently, other whole microorganisms have been tested for their possible immunostimulant properties in fish. Thus, the oral administration or injection of the yeasts Saccharomyces cerevisiae or Candida utilis has been shown to increase both humoral (myeloperoxidase and antibody titer) and cellular (phagocytosis, respiratory burst and cytotoxicity) immune responses, and to increase or confer resistance against pathogenic bacteria in channel catfish, rainbow trout or gilthead seabream [5-8]. Possible use of baker's yeast in fish diets has many advantages. Firstly, they can be produced rapidly, easily and inexpensively and, at the same time, they are very stable and can be recycled from other industries. They are also natural substances so no negative effects may be expected either to the animals or to the environment. Moreover, there is no need to isolate their components, which consists mainly of cell wall sugars ( $\beta$-glucans, mannoproteins and chitin), all are well-proved immunostimulant compounds.

The yeasts (Saccharomyces cerevisiae) has been used in gilthead seabream was Lyophilized form, which is not easily available to the farmer and also very costly but the baker's yeast, which is directly used in the bakery industry is low cost material. With this aim, the present paper discusses the effects of the dietary intake of the baker's yeast as supplementary feed and possible difference with the use of control diets are also established.

\section{Material and Methods}

Fingerlings of the species were obtained from a carp culture farm at the vicinity of Midnapore town has an initial measurement of $12.0 \pm 0.2 \mathrm{~g}$. Fish were $(12.2 \pm 0.22 \mathrm{~g})$ released into continuous flow glass aquaria (76 X 41 X $41 \mathrm{~cm}^{3}$ area; $200.00 \mathrm{l}$ capacity) after acclimatization for 15 days to prevailing laboratory condition of water temperature (31-33 $\left.{ }^{\circ} \mathrm{C}\right)$ and $\mathrm{pH}(7.42-7.53)$. Studies were conducted at room temperature for 60 days. The water quality ( $\mathrm{pH}^{+} \mathrm{DO}$, Alkalinity, Ammonia) of the experimental aquaria was monitored periodically once in a week following the methods of APHA (1998) and maintained at normal level.

\section{Preparation of experimental feeds}

The four prepared feeds (Cont., Exp-1, Exp-2, Exp-3) were formulated using locally available ingredients (mustard oil cake, rice polish, fish meal and tapioca powder). Feed formulation was done basically by "Square method" using determined values of protein content of the different ingredients. Proportion of each ingredient required was calculated precisely providing allowance for the premix. Locally available Baker's Yeast (Saccharomyces cerevisiae) was used as an immune stimulant. Baker's Yeast were diluted in water and supplemented @ 5\%,7.5\% and 10\% in the feed Exp-1, Exp-2 and Exp-3 respectively; where as control feed was not supplemented with Saccharomyces cerevisiae. Feeds were pelleted separately with local made (Kolkata, India) hand pelletiser. The pellets were dried in a thermostatic oven (M/S Modern Industrial Corporation, Mumbai, India) at $37^{\circ} \mathrm{C}$ and less then $10 \%$ moist $[9,10]$ and stored in an air tide jars at room temperature. Proximate composition of the four prepared feeds (Cont., Exp-1, Exp-2, Exp-3) were detailed in (Table 1).

\section{Growth performance and conversion ratio}

Fishes were fed twice daily at 8.00 and $16.00 \mathrm{~h}$ with ration size maintained with $6 \%$ of their body weight in two equal portions. The

*Corresponding author: ArupTewary, Aquaculture Research Unit, Department of Zoology, Vidyasagar University, Midnapore- 721 102, West Bengal, India, Tel: (91) 03222-262297; Fax:(91)03222-262329; E-mail: att tw@rediffmail.com, rup tw@ yahoo.com, bcpatra@yahoo.com

Received November 22, 2010; Accepted January 19, 2011; Published January 22, 2011

Citation: Tewary A, Patra BC (2011) Oral administration of baker's yeast (Saccharomyces cerevisiae) acts as a growth promoter and immunomodulato in Labeo rohita (Ham.). J Aquac Res Development 2:109. doi:10.4172/21559546.1000109

Copyright: ( 2011 Tewary A, et al. This is an open-access article distributed unde the terms of the Creative Commons Attribution License, which permits unrestricted use, distribution, and reproduction in any medium, provided the original author and source are credited. 
net weight was recorded every 15 days with an electronic and feed quality was readjusted after every weighting period of 15 days. For evaluating the dietary performances, the nutritional indices like live weight gain (LWG), Net weight gain (NWG), Average daily growth (ADG), Protein efficiency ration (PER), Specific growth rate (SGR) and Protein efficiency ratio (PER) were used. Two fishes of each group were terminated through overdose anaesthetiasation by MS222 (Sigma chemicals, India) [11] at the end of the experiment, and stored at -20 ${ }^{\circ} \mathrm{C}$ until analysis.

\section{Proximate analysis}

Proximate analyses of ingredients, feeds and body carcass were determined following the method provided in AOAC (1990). Moisture content was determined gravimetrically in a hot air oven at $100+10$ ${ }^{\circ} \mathrm{C}$ for $24 \mathrm{~h}$. Crude protein contents were determined by the microkjeldahl method. Crude lipid contents were determined by the soxhlet extraction method using petroleum ether (Boiling point: $40-60^{\circ} \mathrm{C}$ ) in the electro-thermal soxhlet apparatus. After extraction of lipid the defattend samples were used for the estimation of crude fiber following Patra [12]. Ash content was estimated by inserting samples in a muffle furnace at $500+50^{\circ} \mathrm{C}$ for $10 \mathrm{~h}$.

\section{Biochemical analysis}

DNA (Deoxy-ribo nuclic acid) and RNA (Ribo nuclic acid) contents from liver (hepatopancreas) tissues were estimated as per the scheme given by Munro and Fleck (1969). Tissue was taken from fishes and homogenized with $0.25 \mathrm{~m}$ sucrose solutions. $250 \mu \mathrm{l}$ homogenate and $500 \mu \mathrm{l} 5 \%$ TCA mixed thoroughly centrifuged and wait for 15 minutes and then precipitate was dissolved in PCA (several time in different concentration) and centrifuged with $5000 \mathrm{rpm}$ (two times). The ultimate supernatant was used for RNA and DNA estimation by UV spectrophotometer.

\section{Enzyme assay}

Two specimen from each of the replicate were sampled both the initial stage and at the end of a 60 days experimental period. The fishes were dissected and the liver was cleaned and removed and pieces of liver was thoroughly washed in ice chilled double distilled water and subsequently collected in ice-cooled Petri dishes, weighed and cut into small pieces. A 5\% homogenate was prepared in potter- Elvehjen homogenizer with neutral glass powder and ice cold $0.1 \mathrm{M}$ phosphate buffer ( $\mathrm{pH}-7.4)$ and centrifuged at 2,500 rpm for 15 minutes in a refrigerated centrifuged. The supernatant was used for the GOT and GPT activity following the method of Bernfeld [13].

Initially and after completion of the study, experimental fishes from different feeding trials were separately pooled and liver was dissected out for ACP and ALP activity estimation. After weighting the whole quantity of proportionate quantity, $10 \%$ sucrose and $1 \%$ tritonex mixture were added and the contents homogenized in a tissue homogenizer. The samples were then put in appendrop tube and cold centrifuged (at $-4{ }^{\circ} \mathrm{C}$ ) at $11000 \mathrm{rpm}$ for 15 minutes. The supernatant was collected as sample for determining the ACP [14] and ALP [15] activity.

\section{Study of blood parameters}

Blood samples were collected by heparinized syringe from caudal vein for haematology. EDTA (Ethyline diamine tetraacetic acid) was used as anticoagulant. $1.0 \mathrm{mg}$ EDTA $\mathrm{ml}^{-1}$ of blood or 1 drop of $1.0 \%$ solution $5 \mathrm{ml}^{-1}$ of blood was used for haematology. Haematological parameters were estimated according to the method of Wintrobe [16]. MCV, $\mathrm{MCH}, \mathrm{MCHC}$ were calculated by using standard formulae
(Decie and Lewis 1991). Blood samples were collected in the laboratory for serological diagnosis by syringe from caudal vein and heart. Determination of the Total Serum Protein (TSP) and albumin by Gornall's biuret method [17].

$$
\text { TSG }=\text { TSP- TSA }
$$

(Where TSG $=$ Total Serum globulin, $\mathrm{TSP}=$ Total Serum Protein, $\mathrm{TSA}=$ Total Serum albumin.)

\section{Determination of immunity level}

On day 60, blood was collected form fishes of each group. Part of the blood was heparinised and the rest was allowed to clot for serum samples, which were preserved at $-20^{\circ} \mathrm{C}$ for further analysis. Immediately after collection, the heparinised blood samples of each group were pooled to three aliquots. Part of the blood was analysed for leucocrit value in duplicate per sample [18]. The rest of the heparinised blood was immediately used for the phagocytic assay [8, 19]. Blood was collected from the fish by using a $0.2 \mathrm{ml}$ glass syringe rinsed with an anticoagulant. Then the blood was transferred into the heparinised vial and mix properly. $0.1 \mathrm{ml}$ of freshly prepared NBT solution was added to $0.1 \mathrm{ml}$ of the heparin mixed blood and $15 \mu \mathrm{l}$ of stimulant solution in the incubating bottle. The bottles were incubated at $37^{\circ} \mathrm{C}$ for 10 minutes and at $26^{\circ} \mathrm{C}$ for another 10 minutes. $50-70 \mu \mathrm{l}$ of this blood was transferred onto a clean slide and makes a thick smear with a spreader slide. The slides were air dried and stain with Wright's stain. For staining with the Wright's stain, first flood the slide with $1 \mathrm{ml}$ of the staining solution for 30 seconds then $1 \mathrm{ml}$ of distilled water was added and keep for another 30 seconds. The slide was then pour off the stain and dried. Then the slide was then under oil immersion lens at 100 $\mathrm{X}$. The positive cells had the violet coloured formazan granules in the cytoplasm. The percentage of the positive cells gave the idea about the non-specific immune status of the organism.

\section{Challenge trial}

Rohu fishes (Labeo rohita) of medium size $(435 \pm 28 \mathrm{~g})$ were collected from a semi-intensive culture pond at the University campus. The intestine were gently excised \& cut open with a pair of sterile scissors. The non-adherent micro floras of the intestine were isolated by three times washed with sterile solution \& homogenized with $10 \mathrm{ml}$ distilled water in stomacher bags. The presumptive numbers of micro flora were determined by the spread plate technique using nutrient agar. The pathogenic strain Aeromonas hydrophila (AH1) were isolated by the method of Kaneko [20], which had been cultured and maintained in the Aeromonas selective medium (M884, Hi - Media).

After 60 days feeding trial, fishes of each experimental group were released in four aseptic tanks. Different water quality parameters (Temperature pH, Dissolve Oxygen, Alkalinity, Ammonia) were maintained in normal level. Different experimental feeds and control feeds were provided twice daily according to $6 \%$ of their body weight. The fishes in each treatment were challenged with Aeromonas hydrophila (AH1). Fishes in all replicates were immersed in a suspension of Aeromonas hydrophila (AH1), $\sim 10^{5} \mathrm{CFU} \mathrm{ml}{ }^{-1}$ according to Austin et

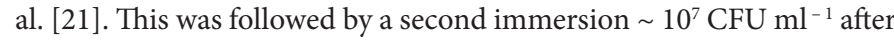
7 days Austin et al. [21]. The survivability of the fishes was recorded against pathogenic strain for last 10 days.

\section{Statistical analyses}

As all the above analyses were carried out on pooled samples of a given lot, standard deviations of means were calculated. However, for evaluating the dietary performances, nutritional indices, enzymatic 
Citation: Tewary A, Patra BC (2011) Oral administration of baker's yeast (Saccharomyces cerevisiae) acts as a growth promoter and immunomodulator in Labeo rohita (Ham.). J Aquac Res Development 2:109. doi:10.4172/2155-9546.1000109

activity and RNA: DNA ratio, different haematological, serological, immunological parameters and challenge trials; correlation and regression test were performed through SPSS software package. Significant differences between the means of the treatments were tested by Duncan Multiple Range Test [22] through SAS software package [23].

\section{Results}

Locally available ingredients (Mustard oil cake, Rich polish and Fish meal) were used for preparing experimental feeds for Labeo rohita. Except control feed (Control), other three experimental feeds (Exp-1, Exp-2 and Exp-3) were supplemented with baker's yeast (Saccharomyces cerevisiae) and it was replaced with equal amount of rich polish. All the four experimental feeds are isocaloric and isonitrogenous. The average crude protein percentage of the feeds were $32.18 \pm 0.22$ and the crude protein percentage were around 7.67 \pm 0.09 (Table 1).

After 60 days feeding trial initial and final carcass composition of Labeo rohita in relation to various feeds was presented in (Table 2 ). The carcass composition of the test animals revealed an apparent increase in the final carcass protein and lipid over the initial carcass

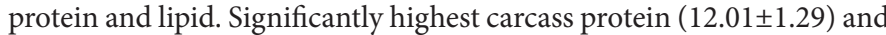
lipid (3.16 \pm 0.31) was recorded in feed Exp-1 fed fishes as compare to other experimental and control feeds. This was clearly indicating that, the enhancement of carcass composition with the increasing supplementation of yeast at a specific level (5\% supplementation). Perhaps it was due to the enzymatic activity in the gut and there by nutrients are spread for the growth and it make overall well being for the fishes.

Maximum weight gain of $135.18 \pm 1.21$ (of 10 fishes) was obtained in feed Exp-1 fed fishes followed by Exp-2 (109.88 11.36$)$ and Exp-3 $(102.86 \pm 1.96)$ and control $(92.82 \pm 1.29)$ respectively (Table 3, Figure $1)$. There were significant differences $(\mathrm{P} \leq 0.05)$ in the different growth parameters among the different experimental feed fed fishes (Table 3 ) Significantly lowest $(\mathrm{P} \leq 0.05)$ FCR $(3.54 \pm 0.033)$ was observed in Exp1 fed fishes; it was also observed that significantly higher SGR was obtained from feed Exp-1 fed fishes (1.27 \pm 0.04$)$. It indicates that Exp-1 feed shows better utilization of nutrients than the other feeds. Similarly significantly $(\mathrm{P} \leq 0.05)$ highest $\mathrm{PER}$ values $(6.46 \pm 0.11) \quad$ was obtained

\begin{tabular}{|c|c|c|c|c|}
\hline \multirow{2}{*}{ Proximate composition of feeds } & \multicolumn{4}{|c|}{ Diets } \\
\hline & Control & $\operatorname{Exp}-1$ & Exp -2 & Exp -3 \\
\hline Moisture(\%) & $7.18^{a}$ & $7.23^{a}$ & $7.19^{a}$ & $7.28^{a}$ \\
\hline Crude protein(\%) & $\begin{array}{c}32.83 \\
\pm 0.13^{\mathrm{a}}\end{array}$ & $\begin{array}{c}32.18 \\
\pm 0.22^{a}\end{array}$ & $\begin{array}{c}31.85 \\
\pm 0.32^{a}\end{array}$ & $\begin{array}{c}31.53 \\
\pm 0.32^{a}\end{array}$ \\
\hline Crude lipid (\%) & $\begin{array}{c}7.92 \\
\pm 0.07^{\mathrm{a}}\end{array}$ & $\begin{array}{c}7.67 \\
\pm 0.09 \mathrm{a}\end{array}$ & $\begin{array}{c}7.54 \\
\pm 0.11^{\mathrm{a}}\end{array}$ & $\begin{array}{c}7.41 \\
\pm 0.23^{a}\end{array}$ \\
\hline Ash(\%) & $\begin{array}{c}11.69 \\
\pm 0.16^{\mathrm{a}}\end{array}$ & $\begin{array}{c}10.62 \\
\pm 0.08^{a}\end{array}$ & $\begin{array}{c}10.08 \\
\pm 0.06^{\mathrm{a}}\end{array}$ & $\begin{array}{c}9.55 \\
\pm 0.19^{\mathrm{a}}\end{array}$ \\
\hline $\begin{array}{c}\text { Energy } \\
\text { (KJ/g) }\end{array}$ & $\begin{array}{c}9.35 \\
\pm 0.004^{\mathrm{a}}\end{array}$ & $\begin{array}{c}9.43 \\
\pm 0.002^{\text {a }}\end{array}$ & $\begin{array}{c}9.46 \\
\pm 0.003^{\text {a }}\end{array}$ & $\begin{array}{c}9.50 \\
\pm 0.008^{\mathrm{a}}\end{array}$ \\
\hline
\end{tabular}

* On dry matter basis.

Results are means of five separate determinations (Mean \pm SEM)

Figures having same alphabets in the different rows are significantly different $(p \leq 0.05)$

Table 1: Proximate composition (\%) of different experimental diets* for Labeo rohita

\begin{tabular}{|c|c|c|c|c|c|}
\hline \multirow{3}{*}{$\begin{array}{c}\text { Carcass } \\
\text { Composition (\%) }\end{array}$} & \multicolumn{5}{|c|}{ Experimental tanks } \\
\hline & \multirow{2}{*}{ Initial } & \multicolumn{2}{|c|}{ Final } & \multirow[b]{2}{*}{ Exp -2 } & \multirow[b]{2}{*}{ Exp -3 } \\
\hline & & Control & $\operatorname{Exp}-1$ & & \\
\hline Crude protein & $\begin{array}{c}7.75 \\
\pm 0.86^{a}\end{array}$ & $\begin{array}{c}9.96 \\
\pm 1.05^{\mathrm{b}}\end{array}$ & $\begin{array}{c}12.01 \\
\pm 1.29^{c}\end{array}$ & $\begin{array}{c}10.40 \\
\pm 0.30^{\mathrm{b}}\end{array}$ & $\begin{array}{r}10.25 \\
\pm 0.65^{\mathrm{b}}\end{array}$ \\
\hline Crude lipid & $\begin{array}{l}2.83 \\
\pm 0.71^{\mathrm{a}} \\
\end{array}$ & $\begin{array}{l}2.90 \\
\pm 0.29^{\mathrm{a}}\end{array}$ & $\begin{array}{c}3.16 \\
\pm 0.31^{\mathrm{a}}\end{array}$ & $\begin{array}{c}2.93 \\
\pm 0.93^{\mathrm{a}}\end{array}$ & $\begin{array}{l}2.99 \\
\quad \pm 0.12^{\mathrm{a}}\end{array}$ \\
\hline Ash & $\begin{array}{c}12.63 \\
\pm 0.062^{\text {a }}\end{array}$ & $\begin{aligned} & 12.55 \\
& \pm 0.089 \text { a } \\
&\end{aligned}$ & $\begin{array}{c}12.89 \\
\pm 0.073^{\text {a }} \\
\end{array}$ & $\begin{array}{c}12.55 \\
\pm 0.062^{\mathrm{a}}\end{array}$ & $\begin{array}{c}12.68 \\
\pm 0.071^{\mathrm{a}}\end{array}$ \\
\hline
\end{tabular}

Results are means of five separate determinations (Mean \pm SEM).

Figures having different alphabets (superscribed) in the same row are significantly different $(p \leq 0.05)$

Table 2: Initial and final carcass composition of fingerlings of Labeo rohita after 60 days experimental trial on four different dietary treatment.

\begin{tabular}{|c|c|c|c|c|c|c|c|c|c|c|}
\hline Diets & NWG (g) & ADG (g) & SGR (\%) & FCR & PER & $\begin{array}{c}\mathrm{Hb} \\
(\mathrm{g} \%)\end{array}$ & $\begin{array}{l}\text { TLC } \\
\left(\times 10^{3} \mathrm{~mm}^{-3}\right)\end{array}$ & $\begin{array}{c}\text { TEC } \\
\left(\times 10^{3} \mathrm{~mm}^{-3}\right)\end{array}$ & Hct $(\%)$ & $\begin{array}{l}\text { Leucocrit } \\
\text { value }\end{array}$ \\
\hline Control & $\begin{array}{c}92.82 \\
\pm 1.29^{a}\end{array}$ & $\begin{array}{c}1.54 \\
\pm 0.002^{\mathrm{a}}\end{array}$ & $\begin{array}{c}0.95 \\
\pm 0.30^{\mathrm{a}}\end{array}$ & $\begin{array}{c}4.64 \\
\pm 0.18^{a}\end{array}$ & $\begin{array}{c}4.35 \\
\pm 0.14^{a}\end{array}$ & $\begin{array}{c}7.1 \\
\pm 0.91^{\text {a }}\end{array}$ & $\begin{array}{c}13.8 \\
\pm 0.76^{\mathrm{a}}\end{array}$ & $\begin{array}{c}1.30 \\
\pm 0.15^{\mathrm{a}}\end{array}$ & $\begin{array}{l}27.21 \\
\pm 1.02^{\mathrm{a}}\end{array}$ & $\begin{array}{c}37.10 \\
\pm 2.05^{\mathrm{a}}\end{array}$ \\
\hline Exp -1 & $\begin{array}{l}135.18 \\
\pm 1.21^{\mathrm{b}}\end{array}$ & $\begin{aligned} & 2.25 \\
\pm & 0.001^{\mathrm{b}}\end{aligned}$ & $\begin{array}{c}1.27 \\
\pm 0.41^{\mathrm{a}}\end{array}$ & $\begin{array}{c}3.54 \\
\pm 0.33^{\mathrm{b}}\end{array}$ & $\begin{array}{c}6.46 \\
\pm 0.11^{\mathrm{b}}\end{array}$ & $\begin{array}{l}8.2 \\
\pm 0.17^{b}\end{array}$ & $\begin{array}{c}22.2 \\
\pm 0.57^{\mathrm{b}}\end{array}$ & $\begin{array}{c}1.76 \\
\pm 0.11^{\mathrm{b}}\end{array}$ & $\begin{array}{c}35.34 \\
\pm 1.25^{\mathrm{b}}\end{array}$ & $\begin{array}{c}59.20 \\
\pm 0.33^{b}\end{array}$ \\
\hline Exp -2 & $\begin{array}{l}109.88 \\
\pm 1.36^{c}\end{array}$ & $\begin{array}{c}1.83 \\
\pm 0.007^{c}\end{array}$ & $\begin{array}{c}1.13 \\
\pm 0.39^{a}\end{array}$ & $\begin{array}{c}4.39 \\
\pm 0.34^{\mathrm{a}}\end{array}$ & $\begin{array}{c}5.30 \\
\pm 0.32^{c}\end{array}$ & $\begin{array}{c}7.9 \\
\pm 0.21^{\mathrm{c}}\end{array}$ & $\begin{array}{c}18.3 \\
\pm 0.76^{c}\end{array}$ & $\begin{array}{c}1.52 \\
\pm 0.06^{c}\end{array}$ & $\begin{array}{c}28.32 \\
\pm 1.41 \mathrm{c}\end{array}$ & $\begin{array}{l}47.50 \\
\pm 1.34^{c}\end{array}$ \\
\hline Exp -3 & $\begin{array}{l}102.86 \\
\pm 1.96^{d}\end{array}$ & $\begin{array}{c}1.71 \\
\pm 0.011^{\mathrm{d}}\end{array}$ & $\begin{array}{c}1.10 \\
\pm 0.30^{\mathrm{a}}\end{array}$ & $\begin{array}{c}4.36 \\
\pm 0.44^{\mathrm{a}}\end{array}$ & $\begin{array}{c}5.02 \\
\pm 0.19^{d}\end{array}$ & $\begin{array}{c}7.5 \\
\pm 0.20^{\mathrm{d}}\end{array}$ & $\begin{array}{c}16.7 \\
\pm 0.87^{d}\end{array}$ & $\begin{array}{c}1.43 \\
\pm 0.14^{\mathrm{d}}\end{array}$ & $\begin{array}{l}32.18 \\
\pm 1.30^{\circ}\end{array}$ & $42.60 \pm 2.13^{d}$ \\
\hline
\end{tabular}

Figures having different alphabets (superscribed) in the same column are significantly different $(p \leq 0.05)$

Table 3: Different growth parameters, haematological parameters and serological parameters after 60 days feeding trial on $L$. rohita with yeast supplemented diets. 
Citation: Tewary A, Patra BC (2011) Oral administration of baker's yeast (Saccharomyces cerevisiae) acts as a growth promoter and immunomodulator in Labeo rohita (Ham.). J Aquac Res Development 2:109. doi:10.4172/2155-9546.1000109

from Exp-1 fed fishes, which indicate better utilization of protein for growth and metabolism.

Significantly $(\mathrm{P} \leq 0.05)$ highest Alkaline phosphatase (ALP) $(8.62 \pm$ $0.04)$ and Acid Phosphatase (1.48 \pm 0.02$)$ activity was observed in Exp1 feed fed fishes (Table 4) following Exp-2 and Exp-3 feed fed fishes. Similarly highest GPT $(0.068 \pm 0.003)$ and GOT $(0.042 \pm 0.002)$ values were registered in feed Exp-1 fed fishes, where as lowest in feed control fed fishes $(0.055 \pm 0.001$ and $0.032 \pm 0.003)$. Significantly $(\mathrm{P} \leq 0.05)$ higher RNA: DNA ratio $(2.10 \pm 0.003)$ was observed in fishes fed with Exp-1 feed and least was recorded $(1.54 \pm 0.001)$ in control feed treated fishes

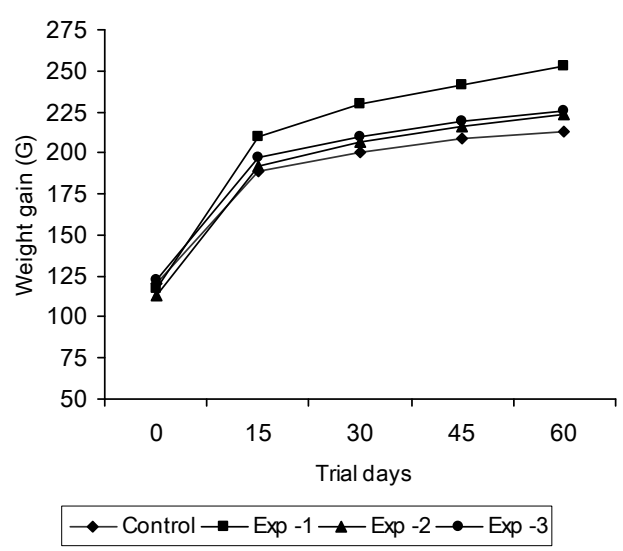

Figure 1: Growth (g) of Labeo rohita in relation to various diets.

\begin{tabular}{|c|c|c|c|c|}
\hline Treatment & ALP & ACP & GOT & GPT \\
\hline Control & $1.08 \pm 0.01^{\mathrm{a}}$ & $0.40 \pm 0.001^{a}$ & $0.032 \pm 0.02^{a}$ & $0.055 \pm 0.001^{\mathrm{a}}$ \\
\hline $\operatorname{Exp}-1$ & $8.62 \pm 0.04^{b}$ & $1.48 \pm 0.02^{b}$ & $0.042 \pm 0.06^{b}$ & $0.068 \pm 0.005^{b}$ \\
\hline Exp -2 & $5.29 \pm 0.02^{c}$ & $1.01 \pm 0.001^{c}$ & $0.039 \pm 0.01^{c}$ & $0.062 \pm 0.002^{c}$ \\
\hline Exp -3 & $5.10 \pm 0.03^{c}$ & $0.73 \pm 0.003^{d}$ & $0.035 \pm 0.04^{d}$ & $0.059 \pm 0.006^{d}$ \\
\hline $\begin{array}{l}\text { ALP (Alkaline } \\
\text { oxaloacetate } \\
\text { transaminase }\end{array}$ & $\begin{array}{l}\text { hosphatase) } \\
\text { ansaminase) } \\
\text { (C 2.6.1.2) }\end{array}$ & \multicolumn{3}{|c|}{$\begin{array}{l}\text { ACP (Acid Phosphatase); } \\
\text { (EC 2.6.1.1); GPT }\end{array}$} \\
\hline
\end{tabular}

Table 4: Activities of ALP. ACP, GOT and GPT in the intestine of Labeo rohita after 60 days feeding trial.

\begin{tabular}{|c|c|c|}
\hline Treatment & Initial & Final \\
\hline Control & & $1.54 \pm 0.001^{\mathrm{an}}$ \\
\hline Exp -1 & \multirow{3}{*}{$1.02 \pm 0.010^{\mathrm{m}}$} & $2.10 \pm 0.003^{\mathrm{b}}$ \\
\hline Exp -2 & & $1.98 \pm 0.005^{\mathrm{c} p}$ \\
\hline Exp -3 & & $1.82 \pm 0.000^{\mathrm{c}}$ \\
\hline
\end{tabular}

Results are means of three separate determinations (Mean \pm SEM),

Values with the same superscript in the different rows are not significantly different $(p<0.05)$

from each other.

RNA/DNA : Initial value $=1.02 \pm 0.010$

Table 5: Initial and final RNA/DNA ratio in the muscle of Labeo rohita after 60 days feeding trial.

\begin{tabular}{|c|c|c|c|c|}
\hline Treatment & $\begin{array}{c}\text { Albumin: } \\
\text { Globulin }\end{array}$ & $\begin{array}{c}\text { Phagocytic } \\
\text { Ratio }\end{array}$ & $\begin{array}{c}\text { Phagocytic } \\
\text { Index }\end{array}$ & NBT cells \\
\hline Control & $3.00 \pm 0.04^{\mathrm{a}}$ & $15 \pm 0.49^{\mathrm{a}}$ & $1.52 \pm 0.12^{\mathrm{a}}$ & $48.5 \pm 0.32^{\mathrm{a}}$ \\
\hline Exp-1 & $2.34 \pm 0.03^{\mathrm{b}}$ & $63 \pm 1.22^{\mathrm{b}}$ & $2.34 \pm 0.09^{\mathrm{b}}$ & $57.0 \pm 0.61^{\mathrm{b}}$ \\
\hline Exp - 2 & $2.52 \pm 0.06^{\mathrm{c}}$ & $42 \pm 1.27^{\mathrm{c}}$ & $2.15 \pm 0.09^{\mathrm{c}}$ & $52.5 \pm 0.24^{\mathrm{c}}$ \\
\hline Exp-3 & $2.49 \pm 0.09^{\mathrm{c}}$ & $18 \pm 0.86^{\mathrm{d}}$ & $1.49 \pm 0.20^{\mathrm{a}}$ & $49.5 \pm 0.23^{\mathrm{d}}$ \\
\hline
\end{tabular}

Results are means of five separate determinations (Mean \pm SEM)

Figures having different alphabets (superscribed) in the same column are significantly different $(p \leq 0.05)$

Table 6: Effect of Yeast (Saccharomyces cerevisiae) on A:G ratio \& non specific Immunity levels of Labeo rohita after 60 days feeding trial.

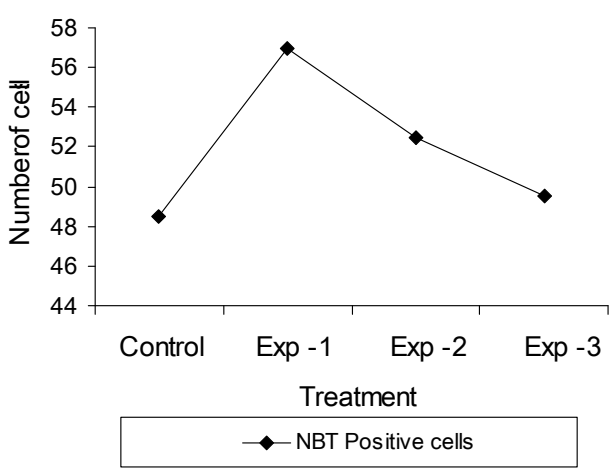

Figure 2: NBT positive cells Number of cells.

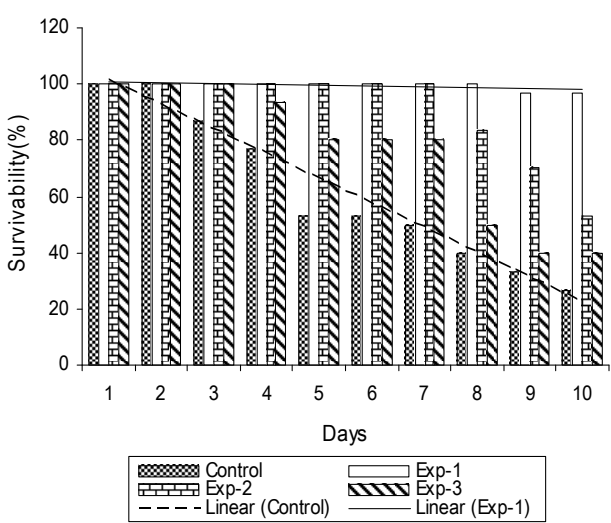

Figure 3: Survivability of Labeo rohita in relation to various diets when challenged with Aeromonas hydrophila ( $\mathrm{AH} 1)$.

(Table 5) after 60 days feeding trial. It was also observed that RNA: DNA ratio of fishes increased in all the treatments over the initial RNA: DNA ratio $(1.02 \pm 0.010)$.

Different Haematological and serological parameters of Labeo rohita after 60 days feeding trial were presented in (Table 3). Significantly $(\mathrm{P} \leq 0.05)$ highest TEC, $\mathrm{Hb}$ and $\mathrm{HCT}$ and lowest Albumin: Globulin ratio were observed in feed Exp-1 fed fishes, where as significantly $(\mathrm{P} \leq 0.05)$ lowest TEC, $\mathrm{Hb}$ and $\mathrm{HCT}$ and highest Albumin: Globulin ratio were recorded in control feed fed fishes after 60 days feeding trial.

The effect of yeast (Saccharomyces cerevisiae) on non-specific immunity was observed. Significantly $(\mathrm{P} \leq 0.05)$ highest phagocytic ratio $(63 \pm 1.22)$, phagocytic index $(2.34 \pm 0.09)$ and leucocrit value (59.20 \pm 0.57$)$ were recorded in Exp-1 feed fed fishes, where as lowest of all these were recorded $(9 \pm 0.49,1.52 \pm 0.12$ and $37.10 \pm 2.05$ respectively) in control feed fed fishes (Table 6). Similar trend was observed in case of number of NBT positive cells. Significantly $(\mathrm{P} \leq 0.05)$ highest number of NBT positive cells $(57.0 \pm 0.61)$ were observed in Exp-1 feed treated fishes and least one $(48.5 \pm 0.32)$ recorded in case of control feeds of Labeo rohita (Table 6, Figure 2).

After 60 days feeding trial all treated and controlled fish faced challenge trial with Aeromonas hydrophila (AH1) for 10 days. After 10 days challenge trial significantly $(\mathrm{P} \leq 0.05)$ highest $(96.66 \%)$ survivability was observed in Exp-1 feed fed fishes followed by Exp-2 (53.33\%), Exp3 (40\%) and control (26\%) feed treated fishes (Figure 3).

\section{Discussion}

In the last two decades, many substances have proved their 
usefulness in fish culture because of their properties to stimulate the immune system \& increase disease resistance. Among these immunostimulants the role of isolated $\beta$-glucans, chitin or vitamins is well documented [24-34]. However, the use of whole organisms instead of their isolated components has hardly been evaluated. In this way whole yeast cells (mainly $S$. cerevisiae), Which represent a major commercial source of $\beta$-glucans, have recently been described as good immiunostimulants in fish $[6,8]$.

Charlon and Bergot [35] achieved more than $89 \%$ survival and good growth of carp larvae; feed exclusively on dry diets having yeast powder and pork / beef freeze dried liver. Alami, Durante et al [36] reported $87 \%$ survival and FCR of 0.62 in common carp larvae reared on liver, yeast and commercial trout starter feed . Singh et al. [37] also found that yeast increased the rate of feed intake and conversion efficiency. Mohanty et al ., reported $100 \%$ survival using a liver based diet containing goat liver, Cod liver oil , Vitamin and mineral mixture with average growth of $133.3 \mathrm{mg} /$ fry in Rohu ( Labeo rohit ) raised from spawn to fry .

In the present study, S. cerevisiae are also found to stimulate the digestion through the supply of digestive enzymes and certain essential nutrients to the animals. Immunostimulants, particularly Saccharomyces cerevisiae producing several enzymes, which is not, produces by the host. Similar observation was also reported by Swain et al. [38]. A complex polysaccharide including cellulose are better utilized by the host in the presence of direct feed microbes like Aspergillus oryza , Saccharomyces cerevisiae.

Furthermore, it was reported that yeast in the diet improves feed efficiency, organic phosphorus (phytic acid) utilization and fibre digestion [38]. It also reported that supplementation of immunostimulants in feed improves the nutrition by hydrolytic enzymes including amylase and proteases, the production of vitamins such as biotin and vitamin $B_{12}$ [39-44] and the host immunity [45]. It indicate that a given amount of immunostimulant elicit more than one protective response by the host.

Dietary intake of immunostimulants by fish has definite advantages and it is a useful method of exposure in large scale fish culture [8], particularly lypopolysaccharides of yeast cell wall was evaluated by many investigators like Ortuno et al. [6]; Sakai [28]; Sahoo and Mukherjee [46]. It is recognized that immunostimulants enhance the host defence system against pathogens by increasing phagocytosis , antibody production, leucocrit level and reduced A:G (Sakai, 1999) . A comparative study done by Ortuno et al. [6] revealed that oral administration of whole yeast Saccharomyces cerevisiae enhances the cellular innate immune response. Notably that all kinds of cellular parameter such as phagocytic index, respiratory burst activity, number of erythrocytes, lymphocytes were also enhanced but not the humoral one.

Blood is a pathophysiological reflector of the whole body and therefore, blood parameters are important in diagnosing the status of fish health (Pecie and Lewis, 1991), particularly when some additives used in the feed. In this present study it was observed that all the blood parameters in all the treatments were similar to standard (Banerjee et al., 2002) and Exp-1 fed fishes showed superior as compare to others, indication of the blood parameters revealed the positive impact, but also demonstrated a stable physiological reflection of the whole body [47]. In this study, a superior growth performance in terms of weight gain percentage, specific growth rate was recorded in $L$. rolita fishes fed with Exp-1 feed as compare to other feed fed fishes. These observations determine the optimum doses of yeast supplementation in feed. This might be helpful for optimum dietary utilization.

In this study, although all the feeds were isonitrogenous but the concentration of immunostimulant i.e. Baker's yeast (S. cerevisoae) in Exp-1 feed might be helpful for proper nutrient utilization. Whole body carcass composition was higher in Exp-1 feed fed fishes as compare to control one, which could have also noted to the overall low feed utilization level. RNA: DNA is known to provide dependable indication of growth trend [48-50]. The ratio was greatest in the fish fed Exp - 1 feed with higher dietary utilization and best growth. Bazaz and keshavnath (1993) found higher RNA: DNA in better growing fish fed with oil supplemented diets using equal level of crude protein. The present study also reports such a finding, where all the feeds are isocaloric and isonitrogenous but 5\% supplementation of Baker's Yeast (S. cerevisiae) incorporated feed ( feed Exp-1 ) exhibit better growth as well as better RNA:DNA ratio. The highest level of GOT and GPT as well as ALP and ACP were found in Exp-1 feed fed fishes and lowest in control. Most of the amino acids normally found in protein undergo transamination reaction and transaminases are localized in both citosol and mitochondria (Wada and Marino, 1964), which is induced by high protein diet [51], thus a positive correlation between the immunostimulant concentration at a specific level and the GOT, GPT level in the liver could be observed.

The result obtain in this study not only support the use of Baker's yeast for better growth, and proper nutrient utilization but also it act as an immunostinunlant by stimulating the immune response. The activation mechanisms involved are known to be related to the carbohydrates, derived from the yeast cell wall. -glucans/whole yeast added to feed stimulates the phagocytic activity, respiratory burst activity and increase protection after challenge with pathogenic bacteria, similar finding ware reviewed by Robertson, 1999.

In this study oral administration of Baker's Yeast (S .cerevisiae) stimulate the non specific immunity level as measured through enhanced phagocytic activity, leucocrit level, respiratory burst activity and reduced A: G. Although enhanced leucocrit value does not necessarily relate to an immunostimulatory action of Baker's Yeast. The possible role of yeast as an imunostimulant due to its cell wall which composed of Lipopolysaccharide, such as glucan, which enhanced phagocytic activity of macrophages and globulin level as observed in the present experiment, the phagocytic indices seemed to be reliable indices of a hightened immunostimulatory response. Similar observation also observed by Swicki et al. [8]; Esteban et al. [31]; Orturo et al. [6]; Radriguezatal [7] in Rainbow trout and gilthread seabream. Albumin Globulin ratio is a measurable humoral component at the non-specific defences. The reduction of A: G, might be due to the increase of Total serum globulin level with Significance protective mechanisms for fish [46]. Fish produce reactive oxygen species, which are considered to be toxic for fish bacterial pathogens $[52,53]$ and are generated by phagocytes after stimulation by a variety of agents. In this experiment higher respiratory burst activity $\left(\mathrm{O}_{2}\right.$ - production) was increased in all the experimental diets as compare to control diets, but highest number of NBT positive cells were observed in Exp-1 feed fed fishes, an effect also seen in rain bow trout ( Siwicki at al,1994), Seabream (Ortuno et al., 2002) and turbot [54]. After challenge trial with Aeromonus hydrophila, highest survivability observed in Exp-1 fed fishes, the enhanced protection conferred by glucan is not surprising, similar report has been reported to induce resistance in carp ( Cyprinus carpio) against $E$. tada [55]. Evidence suggests that glucan enhance disease resistance by stimulating non-specific components of fish immune system [56,57].

To conclude the present results provide evidences that Baker's yeast 
Citation: Tewary A, Patra BC (2011) Oral administration of baker's yeast (Saccharomyces cerevisiae) acts as a growth promoter and immunomodulator in Labeo rohita (Ham.). J Aquac Res Development 2:109. doi:10.4172/2155-9546.1000109

(S. cerevisiae) added in a common fish diet, exhibit better growth, better nutrient utilization and activate the innate immunity, as well as increase the survivability of $L$. rohita. Optimal doses and administration time have been established in an attempt to provide a useful approach for protecting culture fish against infectious diseases.

\section{Acknowledgement}

The authors are thankful to the Department of Science and Technology, government of West Bengal for providing infrastructure facilities. The authors are also thankful to the Department of Zoology for extending all sorts of working facilities and the Research Scholars of the Aquaculture Research Unit, Department of Zoology, Vidyasagar University, for their valuable co-operation to prepare this manuscript.

\section{References}

1. Gatesoupe FJ (1999) The use of probiotics in aquaculture. Aquaculture 180:147-65.

2. Masihi KN (2000) Immunomodulatory agents for prophylaxis and therapy of infections. Intern J of Antimicrobial Agents 14:181-91.

3. Fuller R (1989). Probiotics in man and animals. J of Appl. Bacteriology 66:36578.

4. Tannock GW (1997) Modification of the normal microbiota by diet stress,antimicrobial agents, and probiotics. In: Mackie RI, With BA, Isaacson $\mathrm{RE}$, editors. Gastrointestinal microbes and host interactions. New York: Intern. Thomson Pub 434-65.

5. Chen D, Anisworth AJ (1992) Glucan administration potentiates immune defense mechanisms of channel catfish. Ictahrus punctatus Rafineque. J Fish Dis 15:295-304.

6. Ortuno J, Cuesta A, Rodriguez A, Esteban MA, Meseguer J (2002) Ora administration of yeast, Saccharomyces cerevisiae, enhances the cellula innate immune response of gilthead seabream (Sparus aurata L.). Vet Immuno Immunopathol 85: 41-50.

7. Cuesta RA, Ortuño J, Esteban MA, Meseguer J (2003) Immunostimulant properties of a cell wall-modified whole Saccharomyces cerevisiae strain administered by diet to seabream (Sparus aurata L.). Veterinary Immunology and Immunopathology 96: 183-192.

8. Siwicki, AK, Anderson DP, Rumsey GL (1994) Dietary intake of immuno stimulants by rainbow trout affects non-specific immunity and protection against furunculosis. Veterinary Immunology and Immunopathology 4:125-139.

9. Bazaz MM, Keshavanath P (1993) Effect of feeding levels of sardine oil on growth, muscle composition and digestive enzyme activities of mahseer, Tor khudree. Aquaculture 115:111-119.

10. Keshavanath P, Renuka P (1998) Effect of dietary L-carnitine supplements on growth and body composition of fingerling rohu. Labeo rohita (Ham). Aqua Nutr 4:83-87

11. Bandyopadhyay P, Swain SK, Mishra S (2005) Growth and dietary utilization in gold fish (Carrassius auratus Lin) fed diets formulated with various loca agro- products. Bioresource Tech 96:731-740

12. Patra BC, Maity J, Debnath J, Patra S (2002) Making Aquatic weed useful II: Nymphoides cristatum (Roxb.) O .Kuntze as fish feed for an Indian major carp Labeo rohita (Ham.). Aquaculture Nutrition 8:33-42.

13. Bernfeld P (1955) In. Methods of Enzymology. S.P. Colowick and N.O. Kaplan (Eds), Vol.1, Academic Press, New York. 149.

14. Bramley TA (1975) Treatment of immature mice with gonadotropins. Effects on some enzymatic activities of unfractioned ovarian homogenates. J Biochem 140:451-460

15. Rosauki SR (1993) In: Boehringer Mannheim Gmbh analysis protocol. Clin Chem 39: 648

16. Wintrobe MM (1978) Clinical haematology, (Kipton, H), London, 85-89.

17. Kulow H (1967) Eine Schnellmethode zur Bestimmung der Serumproteine von Satzkarpfen (A rapid method of finding the serum proteins in young common carp). Dt. Fischerei-Ztg. 14: 241-149.

18. Blaxhall P, Daisely K (1973) Routine haematological methods for use in fish blood. J Fish Biol 5:771-781.
19. Park JH, Jeong HD (1996) Enhanced resistance against Edwardsiella trada infection in tilapia (Oreochromis niloticus) by administration of protein bound polysaccharide. Aquaculture 143:135-143.

20. Kaneko S (1971) Microbiological study of fresh fish (2).New Book Indus 13:7680.

21. Austin B, Stuckey LF, Robertson PAW, Effendi I, Griffith DRW (1995) A probiotic strain of Vibrio algilolyticus effective in reducing diseases caused by Aeromonas salmonicida, Vibrio anguillarum and Vibrio ordalii. J Fish Dis 18:93-96.

22. Duncan DB (1955) Multiple range and multiple F-tests. Biometrics 11:1-42.

23. SAS (1991) SAS Institute Inc. SASR system for regression (Second Edn), SAS Institute Inc, Cary, NC, 210

24. Di Luzio NR (1979) Lysozyme, glucan-activated macrophages and neoplasia. J Reticuloendothel Soc 26:67-81.

25. Czop JK, Austen KF (1985) A beta-glucan inhabitable receptor on human monocytes: its identity with the phagocytic receptor for particulate activators of the alternative complement pathway. J Immunol 134:2588-2593.

26. Hardie LJ, Fletcher TC, Secombes CJ (1991) The effect of dietary vitamin C on the immune response of Atlantic salmon (Salmo salar). Aquaculture 95:201214

27. Yano T, Matsuyma H, Mangindaan REP (1991) Polysaccharide-induced protection of carp. Cyprinus carpio L. against bacterial infection. J Fish Dis 14:577-582

28. Sakai M (1999) Current research status of Fish Immunostimulants. Aquaculture 172: 63-92.

29. Thompson I, White A, Fletcher TC, Houlihan DF, Secombes CJ (1993) The effect of stress on the immune response of Atlantic salmon (Salmo salar L.) fed diets containing different amount of vitamin C. Aquaculture 114:1-18.

30. Esteban MA, Cuesta A, Ortuno J, Meseguer J (2001) Immunomodulatory effects of dietary intake of chitin in gilthead seabream (Sparus aurata L.) innate immune response. Fish Shellfish Immunol 11:305-315.

31. Esteban MA, Mulero V, Cuesta A., Ortuño J, Meseguer J (2000) Effects of injecting chitin particles on the innate immune responses of gilthead seabream (Sparus aurata L.). Fish Shellfish Immunol 10:543-554.

32. OrtuñJ, Cuesta A, Esteban MA, Meseguer J (2001) Effect of oral administration of high vitamin $\mathrm{C}$ and $\mathrm{E}$ dosages on the gilthead seabream (Sparus aurata $\mathrm{L}$.) innate immune system. Vet Immunol Immunopathol 79:167-80.

33. Cuesta A, Esteban MA, Meseguer J (2001) Vitamin E increases natural cytotoxic activity in seabream (Sparus aurata L.). Fish Shellfish Immunol 11:293-302.

34. Cuesta A, Ortun OJ, Rodriguez A, Esteban MA, Meseguer J (2002) Changes in some innate defence parameters of seabream (Sparus aurata L.) induced by retinol acetate. Fish \& Shellfish Immunol 13:279-291.

35. Charlon N, Bergot P (1984) Rearing system for feeding fish larvae on dry diets Trial with carp (Cyprinus carpio) larvae. Aquaculture 54:83-88.

36. Alami- Durante H, Charlon N, Escafree AM, Bergot P (1991) Supplementation of artificial diets for common carp (Cyprinus carpio L.) larvae. Aquaculture 93:167-175

37. Singh BN, Sinha VRP, Chakrobarty DP (1980) Feeding intake, absorption conversion and growth of fry fingerlings of rohu, Labeo rohita. Indian J Fish 27:193-200.

38. Swain SK, Rangacharyulu PV, Sarkar S, Das KM (1996) Effect of a probiotic supplement on growth, nutrient utilization and carcass composition in mrigal fry. J Aqua 4: 29-35.

39. Fuller R, Turvy A (1971) Bacteria associated with the intestinal wall of the fow (Galtus domesticus). J Appl Bacteriology 66:365-378.

40. Parker RB (1974) Probiotics-The other half of the antibiotics story. Anim Nutr Health. 29: 1416-1422.

41. Roach S, Tannock GW (1980) Indigenous bacteria that influence the number of Salmonella typhimurium in the spleen of intravenously challenged mice. Canadian J Microbiol 26:408-411.

42. Sugita $H$, Miyajima $C$, Deguchi $H$ (1991) The vitamin $B_{12}$ producing ability of the intestinal microflora of fresh water fish. Aquaculture 92:267-276.

43. Fuller R (1992) History of development of probiotics. In. Fuller,R. (Ed), Probiotics: the scientific basis, Chapman and hall, New York. 1-8. 
Citation: Tewary A, Patra BC (2011) Oral administration of baker's yeast (Saccharomyces cerevisiae) acts as a growth promoter and immunomodulator in Labeo rohita (Ham.). J Aquac Res Development 2:109. doi:10.4172/2155-9546.1000109

44. Sugita H, Takahashi J, Deguchi H (1992) Production and consumption of biotin by the intestinal microflora of cultured fresh water fishes. Biosciences. Biotech and Biochem 56: 1678-1679.

45. Gibson GR., Saavendra J M, MacFarlane S, MacFarlane GT (1997) Probiotics and intestinal infection. In Probiotics 2, Application and Practical Aspects (ed. By R. Fuller). Chapman and Hall, London.

46. Sahoo PK, Mukherjee SC (2001) Immuonocompressive effect of aflatoxin $B_{1}$ in Indian major carp (Labeo rohita). Comp immunol Micro Inf Dis 24:143-9.

47. Decie SIV, lewis SM (1991) Practical haematology (VII Edn). J and A Chuechill Ltd. , Livingston, London, Melbourne and NewYork.

48. Buckley LJ (1980) Changes in ribonucleic acid, deoxyribonuclc acid and protein content during ontogenesis in winter flounder Pseudopleuronectes amouricauses and effect of starvation . U.S. Fish Bull 77:703-708.

49. Khan MA, Jafri AK (1991) Protein and nucleic acid concentration in the muscle of catfish Clarias batrachus. Asian Fish Sci 4:75-84.

50. Banerjee SK, Patra BC, Bandyopadhyay P, Tewary A (2002) Changes of the blood parameters in an Indian major carps, Catla catla Ham. Due to Myxozoan parasites infection. Indian J of Aquatic Biol 17: 79-84.
51. Swicki RW, Barnstein PL, Strange JL (1965) The response of the isozymes of alanine aminotransferase to diet and hormones. J Biol Chem. 240:3341-3345.

52. Hardie LJ, Ellis AE, Secombs CJ (1996) In vitro activation of rainbow trout macrophages stimulates inhibition of Renibacterium salmoninarum growth concomitant with augmented generation of respiratory burst products. Disease of Aquatic Organism 25: 175-183.

53. Itou T, lida T, Kawatsu H (1996) The importance of hydrogen peroxide in phagocytic bactericidal activity of Japanese eel neutrophils. Fish pathology 3:121-125.

54. Toranzo AE, Devesa S, Romalde JL, Lamas J, Riaza A, et al. (1995) Efficacy of intraperitoneal and immersion vaccination against Enterococcus sp. infection in turbot. Aquaculture 134:17-27.

55. Yano T Mangindaan REP, Matsuyama H (1989) Enhancement of the resistance of carp Cyprinus carpio to experimental Edwardsiella tarda infection, by some -1,3 -glucans, Nippon Suisan Gakkaishi 55:1815-1819.

56. Association of Officials Analytical Chemistry (AOAC), (1990) Official methods of analysis. $15^{\text {th }}$ Edn. Edited by S. Williams, AOAC, Virginia, $1298 \mathrm{pp}$.

57. American Public Health Association (1998) Standard method for the Examination of water and wastewater, $20^{\text {th }}$ edn. APHA, Washington, DC, USA 